\title{
Review: In vivo and postmortem effects of feed antioxidants in livestock: a review of the implications on authorization of antioxidant feed additives
}

\author{
S. A. Salami ${ }^{1 a \dagger}$, A. Guinguina ${ }^{1 \mathrm{~b}}$, J. O. Agboola ${ }^{2}$, A. A. Omede ${ }^{3}$, E. M. Agbonlahor ${ }^{4}$ and \\ U. Tayyab ${ }^{2 c}$
}

${ }^{1}$ Department of Animal Sciences, Wageningen University, De Elst 1, 6708WD Wageningen, The Netherlands; ${ }^{2}$ Department of Animal Sciences, Aarhus University, DK-8830 Tjele, Denmark; ${ }^{3}$ School of Environmental and Rural Science, University of New England, Armidale NSW 2351, Australia; ${ }^{4}$ Department of Animal Production, University of Ilorin, P.M.B. 1515 Ilorin, Nigeria

(Received 28 December 2014; Accepted 30 November 2015; First published online 14 January 2016)

The pivotal roles of regulatory jurisdictions in the feed additive sector cannot be over-emphasized. In the European Union (EU), antioxidant substances are authorized as feed additives for prolonging the shelf life of feedstuffs based on their effect for preventing lipid peroxidation. However, the efficacy of antioxidants transcends their functional use as technological additives in animal feeds. Promising research results have revealed the in vivo efficacy of dietary antioxidants for combating oxidative stress in production animals. The in vivo effect of antioxidants is significant for enhancing animal health and welfare. Similarly, postmortem effect of dietary antioxidants has been demonstrated to improve the nutritional, organoleptic and shelf-life qualities of animal products. In practice, dietary antioxidants have been traditionally used by farmers for these benefits in livestock production. However, some antioxidants particularly when supplemented in excess could act as prooxidants and exert detrimental effects on animal well-being and product quality. Presently, there is no exclusive legislation in the EU to justify the authorization of antioxidant products for these in vivo and postmortem efficacy claims. To indicate these efficacy claims and appropriate dosage on product labels, it is important to broaden the authorization status of antioxidants through the appraisal of existing EU legislations on feed additives. Such regulatory review will have major impact on the legislative categorization of antioxidants and the efficacy assessment in the technical dossier application. The present review harnesses the scientific investigations of these efficacy claims in production animals and, proposes potential categorization and appraisal of in vivo methodologies for efficacy assessment of antioxidants. This review further elucidates the implication of such regulatory review on the practical application of antioxidants as feed additives in livestock production. Effecting these regulatory changes will stimulate the innovation of more potent antioxidant products and create potential new markets that will have profound economic impacts on the feed additive industry. Based on the in vivo efficacy claims, antioxidants may have to contend with the legislative controversy of either to be considered as veterinary drugs or feed additives. In this scenario, antioxidants are not intended to diagnose or cure diseases as ascribed to veterinary products. This twisted distinction can be logically debated with reference to the stipulated status of feed additives in Commission Regulation (EC) No 1831/2003. Nonetheless, it is imperative for relevant stakeholders in the feed additive industry to lobby for the review of existing EU legislations for authorization of antioxidants for these efficacy claims.

Keywords: antioxidant, feed additive, legislation, oxidative stress, product quality

aPresent address: Di3A, Animal Production Science, University of Catania, Via Valdisavoia, 5, 95123 Catania, Italy.

bPresent address: Department of Agricultural Research for Northern Sweden, Swedish University of Agricultural Sciences, S-901 83 Umeå, Sweden.

'Present address: Department of Animal Production, Welfare and Veterinary Sciences, Harper Adams University, Edgmond Newport Shropshire, TF10 8NB, UK.

${ }^{\dagger}$ E-mail: sayodeji14@yahoo.com

\section{Implications}

A multitude of studies have shown that dietary antioxidants can alleviate oxidative stress in livestock and improve the quality of animal products. This review highlights the need for appraisal of feed additive legislations in the European Union to exclusively ascribe these efficacy claims to the authorization of antioxidants. This will give broader and 
defined marketing perspectives to the uses of antioxidants with consequent impacts on the feed additive industry and market. Inclusion of these claims and required dosages on product labels will better guide feed manufacturers, nutritionists and livestock producers in their purchasing decisions and application of antioxidants.

\section{Introduction}

Historically, antioxidants have been added to commercial feeds to prevent lipid peroxidation and oxidative rancidity during production, processing and storage of feeds. More importantly, the current trend of formulating diets with polyunsaturated fatty acids (PUFAs)-rich ingredients has heightened the use of antioxidants in animal feeds. Indeed, PUFA-rich foods and feeds are highly susceptible to lipid peroxidation (Decker et al., 2012). The use of exogenous antioxidants in commercial feeds helps to preserve the sensory qualities of the feed and prevent the destruction of critical nutrients such as pigments and vitamins (Calabotta and Shermer, 1985). Interestingly, the biological activities of antioxidants have been well-established in both humans and animals aside from their activities in foods and feeds (Halliwell and Gutteridge, 1999; Surai, 2007; Kalam et al., 2012). As illustrated in Figure 1, the biological effects of supplemental antioxidants could accumulate into in vivo and postmortem benefits by preventing oxidative stress and oxidative rancidity in production animals and animal food products, respectively (Fellenberg and Speisky, 2006).

There is an important global focus on the legislative frameworks regulating the authorization of feed additive products due to the overwhelming significance of feed additives in modern livestock production. There are vast disparities in the regulatory status of antioxidants as feed additives when considered across different countries. Commission Regulation (EC) No 1831/2003 (Commission Regulation, 2003) guides the authorization of feed additives in the European Union (EU). Feed additives can be authorized, based on their efficacy claims, into one of the five existing functional groups (i.e. technological, sensory, nutritional, zootechnical, coccidiostats and histomonostats additives). Presently, antioxidant substances are authorized as feed additives for prolonging the shelf life of feedstuffs based on their effect for preventing lipid peroxidation. Antioxidant substances are exclusively categorized under the 'technological additives' functional group. Moreover, vitamins and trace minerals are categorized as a functional group in the category of 'nutritional additives' even though certain vitamins and trace minerals could exhibit antioxidative activity. It is crystal clear that the present EU regulations for authorization of antioxidants as feed additives lack exclusive consideration for the in vivo and postmortem effects of antioxidants in livestock. Indeed, regulatory recognition of the in vivo and postmortem efficacies of antioxidant products may be a major stumbling block for the global feed additive industry and market.

In recent years, extensive scientific reviews have elucidated the in vivo and/or postmortem benefits of antioxidant nutrition in production animals (Fellenberg and Speisky, 2006; Celi and Chauhan, 2013; Castillo et al., 2013; Salami et al., 2015). This review is exclusively aimed at describing the roles of antioxidants as feed additives with respect to animal well-being and product quality. This review further exploits how these efficacy claims could stimulate the appraisal of legislations guiding the authorization of antioxidants as feed additives in the EU.

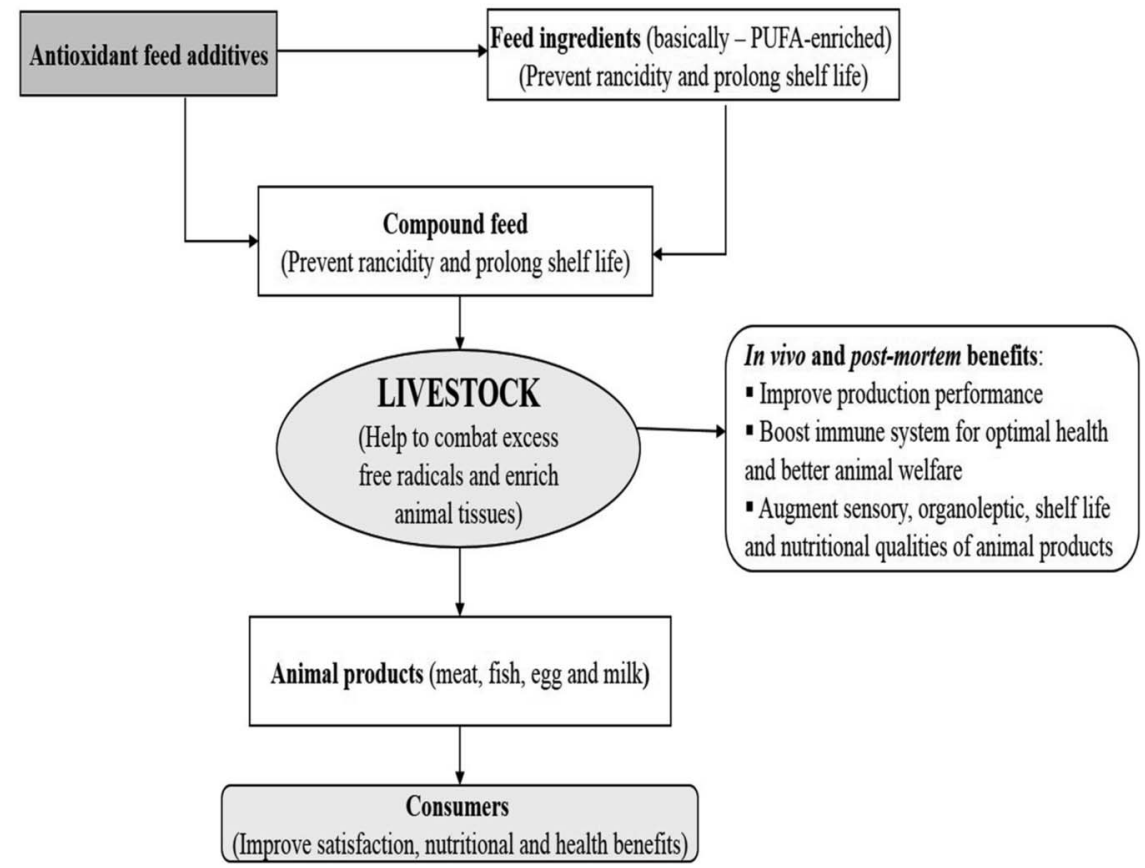

Figure 1 Schematic concept of in vivo and postmortem benefits of antioxidants in livestock. PUFA = polyunsaturated fatty acid. 


\section{Feed antioxidants}

Halliwell and Gutteridge (1999) defined antioxidants as substances that when present in feeds and foods at a concentration lower than that of an oxidizable substrate will significantly interrupt or avert the oxidation of the substrate. Hilton (1989) and Decker (1998) noted that substances that could exhibit antioxidative capacity include deactivators of peroxides and other reactive oxygen species; quenchers of secondary lipid oxidation products that produce rancid odors; oxygen scavengers; free radical scavengers and metal chelates. Antioxidants used in animal feeds are functionally considered to be similar to those used in food and they can be broadly categorized into natural and synthetic ones. Several authors (Shahidi, 2000; Shahidi and Zhong, 2005; Augustyniak et al., 2010) have provided detailed overview as well as the regulatory status of natural and synthetic antioxidants in foods and feeds; thus, a concise discussion will be provided in this review.

\section{Natural antioxidants}

These are antioxidants that exist naturally in plant-based materials and predominantly include vitamins and polyphenolic compounds. Albeit there are quite a number of antioxidants in nature, only few are commercially used as additives for combating feed peroxidation. Vitamin $\mathrm{E}$ (tocopherols and structurally related tocotrienols) and vitamin C (ascorbic acid) are the most significant natural antioxidants used in feeds (Shahidi and Zhong, 2005). Others include vitamin A (retinol) and carotenoids. Substantial quantities of these natural antioxidants can be present in feed ingredients including vegetable oil, legumes and cereals. Animals fed forages could also have access to substantial quantities of these vitamins as well as polyphenolic compounds (Castillo et al., 2013). Factors such as the type of forage species, conservation methods and the forage maturity status could, however, affect the concentration of vitamins in forages; thereby demanding for exogenous supply of dietary antioxidants (Lindqvist, 2012).

Commercial forms of vitamins can be produced either by fermentation, chemical synthesis or extraction from natural sources. Synthetic derivatives of vitamins can be largely similar in chemical structures to their corresponding naturally occurring forms in plants (Topliss et al., 2002). The antioxidant stability and activity of tocopherols depend on temperature and vary with their chemical structure. The antioxidant activity of tocopherols in foods decreases in the order of $\delta$ - $>\gamma^{-}>\beta->\alpha$-tocopherol (Shahidi, 2000). However, the biological efficacy of the synthetic derivatives could differ from their natural forms. For instance, the biological activity of the synthetic derivative of vitamin $E$, allrac- $\alpha$-tocopherol (a mixture of eight stereoisomers) is lower than that of its natural form RRR- $\alpha$-tocopherol in a given ratio of 1:1.36 (Weiser and Vecchi, 1982). This could be explained by the better bioavailability of RRR- $\alpha$-tocopherol compared with all-rac- $\alpha$-tocopherol (Traber et al., 1998). The eight stereoisomers could also vary in their biopotencies with the RRR form being the most active (Weiser and Vecchi, 1982). The bioavailability of these stereoisomers has been further demonstrated to vary in fluids and tissues of different animal species (Jensen and Lauridsen, 2003). In addition, there are indications that vitamin $\mathrm{E}$ is more effective in vivo while vitamin $C$ acts effectively postmortem (Morrissey et al., 1998; Bou et al., 2001).

Furthermore, botanicals rich in polyphenols such as rosemary extract, grape pomace (GP), grape seed extract, green tea and olive oil, have been tested and still undergoing extensive evaluation as natural antioxidants in feeds. The in vitro and in vivo antioxidant protection of phytochemicals could be mediated by direct scavenging of free radicals, which could be partly influenced by their low values of standard one-electron reduction potential (Augustyniak et al., 2010). In addition, it could indirectly involve the complex mechanism of activating the nuclear factor erythroid-2, nuclear-related factor 2 (Nrf2) and Kelch-like ECH associated protein 1 (Keap1) complex. Activation of the Nrf2-Keap1 complex could then induce a cytoprotective mechanism against free radicals (Lee et al., 2013). Several factors could influence the physiological functions of phytochemicals. These include the composition of the raw material, processing methods, location of bioactive compounds within the tissue as well as factors influencing solubilization, micelle formation, transporter for uptake and factors influencing in vivo metabolism (Bohn et al., 2015). The major drawbacks associated with the development of botanicals as natural antioxidants include the assessment of their antioxidant potency as well as the separation of their individual phytochemicals (Augustyniak et al., 2010). Moreover, many of the phytochemicals have low bioavailability and there is extensive need to identify phytochemicals with high bioavailability to enhance their biological activities (Manach et al., 2004).

Indeed, natural antioxidants have green image and are becoming more acceptable to consumers than their synthetic counterparts. Similarly, the safety assessment of natural antioxidants is less-stringent compared with synthetic antioxidants and most of them are enlisted with GRAS (generally recognized as safe) status for authorization.

\section{Synthetic antioxidants}

These are chemically synthesized and are required at low concentrations to stabilize oil, fat and lipid-containing feeds. They are mostly phenolic and nitrogen compounds and the phenolic derivatives contain more than one methoxy or hydroxyl groups. The most commonly used synthetic phenolic compounds include butylated hydroxytoluene (BHT), butylated hydroxyanisole (BHA), tert-butylhydroquinone (TBHQ) and propyl gallate (Shahidi and Zhong, 2005). Phenolic compounds execute their antioxidant function by capturing free radicals and halting oxidation chain reaction. Examples of nitrogen compounds include ethoxyquin (EQ), capsaicin and vanillylamide, of which EQ remains the most efficacious. Synthetic antioxidants are generally perceived to be more effective than equal quantities of natural antioxidants and can better resist processing losses (Crane et al., 2000). 
The use of EQ and other synthetic antioxidants for in vivo benefits must be extensively tested for the absence of carcinogenicity and other toxic effects in their pure and oxidized forms as well as their reaction products with feed components (Augustyniak et al., 2010; Błaszczyk et al., 2013). In addition, the residues of synthetic antioxidants and their metabolites in animal foods may hamper the use of synthetic antioxidants for postmortem benefits. Consumption of $300 \mathrm{~g}$ fillet was shown to contribute significantly to the acceptable daily intake of BHT as well as EQ and its oxidation products, when included in the diets of farmed Atlantic salmon (Lundebye et al., 2010). Moreover, the feed dosage of these synthetic antioxidants and their duration of exposure in animals could be directly related to the amount of their residues in animal foods as shown for EQ in the fillet of Atlantic salmon (Bohne et al., 2008). In contrast, the amount of $E Q$ in foods of animal origin was less than the EU maximum residue level (Aoki et al., 2010). Indeed, there is crucial need for regulatory monitoring of both $\mathrm{EQ}$ and its oxidation products as well as that of other synthetic antioxidants in animal foods considering their potential toxicity in humans (Błaszczyk et al., 2013). Nonetheless, the US Food and Drug Administration regulated for maximum inclusion level of $150 \mathrm{ppm}$ for EQ, $200 \mathrm{ppm}$ for both BHT and $\mathrm{BHA}$ in animal feeds and similar regulatory levels have been adopted by many other countries including the EU.

\section{Effects of supplemental antioxidants in livestock}

\section{Mechanisms of antioxidant protection}

The mechanisms of antioxidant protection in the biological system of animals have been extensively reviewed by several authors (Fellenberg and Speisky, 2006; Lykkesfeldt and Svendsen, 2007; Surai, 2007). Thus, a succinct detail will be provided in this review. In reality, the animal is naturally endowed with an overwhelming biological antioxidant system to combat the free radicals that are continuously produced as a result of several metabolic activities in the body. Free radicals include reactive oxygen species and reactive nitrogen species such as superoxide anion, hydroxyl radical and hydrogen peroxide (Kalam et al., 2012). However, there is a certain limit to the protection that could be offered by the endogenous antioxidant barrier. This limit is further compromised by the presence of factors that could trigger excessive production of free radicals and/or weaken the efficiency of the biological antioxidant system, thereby causing oxidative stress. Such factors include: consumption of high-PUFA or rancid diet; intake of mycotoxins, heavy metals, fungicides and pesticides; nutritional deficiency such as selenium; pathogenic infections; stress-related practices such as weaning, vaccination and transportation; exposure to ionizing radiation; animal's production status such as early lactation; and heat stress. Furthermore, once animals are slaughtered, there is concomitant loss of efficiency in the biological antioxidant system, which together with other post-slaughter conditions (Morrissey et al., 1998) result in the onset of lipid deterioration in muscle tissues and consequent oxidative rancidity in meat products (Iglesias et al., 2008).

Free radicals are unstable and highly reactive chemical species with an unpaired electron which induces them to trap electron from biological macromolecules such as DNA, lipids and proteins, in order to neutralize themselves. The reaction of free radicals with biological molecules results in oxidative damage of such macromolecules and potential cellular damage (Fellenberg and Speisky, 2006). In a counter protective response, antioxidants act by either directly scavenging the free radicals or stabilizing the free radicals by donating the electron needed (Figure 2). As presented in Table 1, the biological antioxidant system consists of both the enzymatic (superoxide dismutase (SOD), glutathione peroxidase (GSH-Px), catalase (CAT), etc.) and non-enzymatic (selenium, vitamins $E, C$ and $A$, etc.) components. In essence, oxidative stress is the deteriorative condition, which results from the imbalance between the endogenous generation of free radicals and the biological antioxidant defense systems in the body (Halliwell and Gutteridge, 1999). In situations of excess free radical production, there is a keen need for exogenous intake of antioxidants to prevent potential cellular damage.

Based on the nature of antioxidants, they can be grouped into water-soluble (e.g. ascorbic acid) and lipid-soluble (e.g. vitamin $\mathrm{E}$ and carotenoids) antioxidants. The former and the latter are located in the hydrophilic and lipophilic compartments of the cell, respectively (Yeum et al., 2004). There are emerging indications that redox cooperation exist between these two groups of cellular antioxidants, which accumulate to antioxidant synergism. Example of such redox cooperation is the ability of terminal hydrophilic ascorbic acid to repair oxidized tocopheroxyl radical of vitamin E in order to allow vitamin $\mathrm{E}$ perform its antioxidant function again (Buettner, 1993). Similarly, Iglesias et al. (2008) demonstrated that exogenous phenolic compound, grape procyanidins, had the ability to repair oxidized $\alpha$-tocopherol and delay the depletion of ascorbic acid in the muscle tissues of fish. Thus, this highlights the importance of supplementing livestock with both groups of antioxidants to enhance duality of action which has proven to have synergistic effects.

\section{In vivo efficacy in livestock}

A multitude of published studies have highlighted the benefits of antioxidants on the health and production of livestock. Thus, the information provided in this review should be considered as an overview. Several comprehensive review papers have elucidated the deteriorative role of oxidative stress and the in vivo benefits of antioxidant nutrition in farm animals (Lykkesfeldt and Svendsen, 2007), ruminants (Miller et al., 1993a; Hansen, 2010; Celi, 2011) and poultry (Surai, 2002; Fellenberg and Speisky, 2006; Surai, 2007).

\section{Poultry}

Several factors which could be of nutritional, pathological, physiological or environmental origins could induce oxidative stress and impair the performance of chickens 


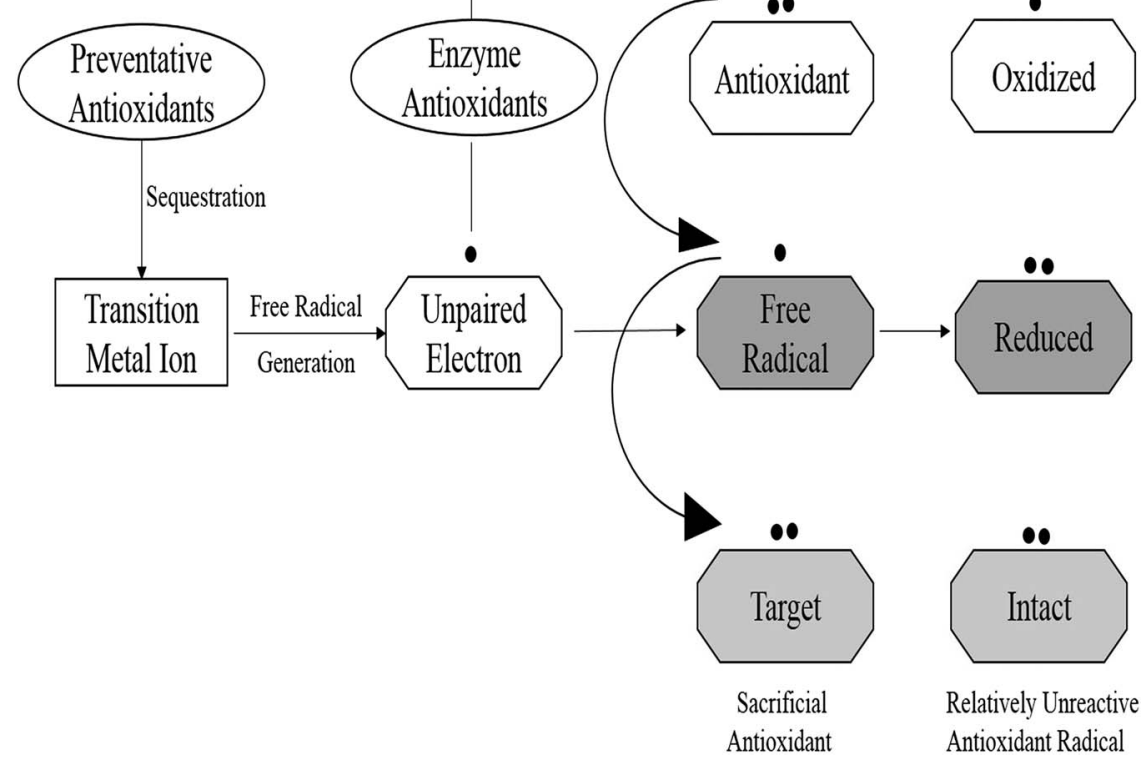

Figure 2 Mechanism of action of antioxidants (adapted from Kalam et al., 2012).

Table 1 Antioxidants in the biological system of animals (adapted from Weiss, 2010)

\begin{tabular}{|c|c|c|}
\hline $\begin{array}{l}\text { Component } \\
\text { (location in cell) }\end{array}$ & $\begin{array}{l}\text { Nutrients } \\
\text { involved }\end{array}$ & Function \\
\hline $\begin{array}{l}\text { Superoxide dismutase } \\
\text { (cytosol) }\end{array}$ & $\mathrm{Cu}$ and $\mathrm{Zn}$ & $\begin{array}{l}\text { An enzyme that converts } \\
\text { superoxide to hydrogen } \\
\text { peroxide }\end{array}$ \\
\hline $\begin{array}{l}\text { Superoxide dismutase } \\
\text { (mitochondria) }\end{array}$ & $\mathrm{Mn}$ and $\mathrm{Zn}$ & $\begin{array}{l}\text { An enzyme that converts } \\
\text { superoxide to hydrogen } \\
\text { peroxide }\end{array}$ \\
\hline Ceruloplasmin & $\mathrm{Cu}$ & $\begin{array}{l}\text { An antioxidant protein, may } \\
\text { prevent copper from } \\
\text { participating in oxidation } \\
\text { reactions }\end{array}$ \\
\hline $\begin{array}{l}\text { Glutathione peroxidase } \\
\text { (cytosol) }\end{array}$ & Se & $\begin{array}{l}\text { An enzyme that converts } \\
\text { hydrogen peroxide to } \\
\text { water }\end{array}$ \\
\hline Catalase (cytosol) & $\mathrm{Fe}$ & $\begin{array}{l}\text { An enzyme (primarily in } \\
\text { liver) that converts } \\
\text { hydrogen peroxide to } \\
\text { water }\end{array}$ \\
\hline $\begin{array}{l}\alpha \text {-Tocopherol } \\
\quad \text { (membranes) }\end{array}$ & Vitamin E & $\begin{array}{l}\text { Breaks fatty acid } \\
\text { peroxidation chain } \\
\text { reactions }\end{array}$ \\
\hline$\beta$-Carotene (membranes) & $\beta$-Carotene & $\begin{array}{l}\text { Prevents initiation of fatty } \\
\text { acid peroxidation chain } \\
\text { reactions }\end{array}$ \\
\hline
\end{tabular}

(Salami et al., 2015). Consequently, dietary antioxidants have been shown to counteract the negative effects of oxidative stress in poultry and extensive reviews have been provided for broiler chickens (Fellenberg and Speisky, 2006; Salami et al., 2015). Table 2 depicts the recommended dietary antioxidant nutrients in poultry.
Mint leaves, amla electrolyte and vitamin E supplemented as dietary antioxidants, enhanced the antioxidant status of broilers reared under heat stress (Maini et al., 2007). Glutathione (GSH) concentration was higher with mint leaves and electrolyte supplements while SOD activity was found highest in brain, liver and heart with amla electrolyte and vitamin E. Taulescu et al. (2011) reported that supplementation of vitamin $\mathrm{E}$ and selenium (Se) positively influenced the BW gain in broilers fed oxidized lipids but no effect was observed on the carcass characteristics of the birds. Increased SOD and CAT activity, higher ferric reducing antioxidant power (FRAP) and significantly lower malondialdehydes (MDA) were reported in heat stress layer and breeder hens supplemented with vitamins $E$ and $C$ (Yardibi and Turkay, 2008; Jena et al., 2013). Conversely, feeding singly or a combination of natural antioxidant supplements of grape seed extracts, tomato extracts, rosemary extracts, green tea extracts and natural tocopherols did not affect the oxidative status and lipid oxidation of plasma in broilers (Vossen et al., 2011). Though low inclusion dose was suggested as a possible cause for the observed tenuous antioxidant effect. In a study evaluating synthetic antioxidants, EQ and propyl gallate decreased liver thiobarbituric acid reactive substances (TBARS) levels when broilers were fed diet containing oxidized oil (Tavarez et al., 2010).

There may be potential to complement the antioxidant activity of dietary vitamin $\mathrm{E}$ with that of phenolic extracts even though there are limited data in this regard. It was recently highlighted that polyphenol-rich grape by-products could partially replace costly vitamin $\mathrm{E}$ in monogastric diets by finding the right proportion to combine them (Brenes et al., 2015). There was significant positive effect on the growth performance of broilers when grape extracts were supplemented in combination with $100 \mathrm{ppm}$ of 
Salami, Guinguina, Agboola, Omede, Agbonlahor and Tayyab

Table 2 Recommended dietary antioxidant nutrients for various classes of poultry per ton of complete feed (adapted from Waldroup, 2001)

\begin{tabular}{lccccrrr}
\hline \hline $\begin{array}{l}\text { Vitamins/ } \\
\text { minerals }\end{array}$ & $\begin{array}{c}\text { Starting (0 to } \\
\text { 8 weeks) }\end{array}$ & $\begin{array}{c}\text { Growing (8 to } \\
18 \text { weeks) }\end{array}$ & $\begin{array}{c}\text { Hens (egg } \\
\text { type) }\end{array}$ & Breeders & $\begin{array}{c}\text { Turkey (0 to } \\
8 \text { weeks) }\end{array}$ & $\begin{array}{c}\text { Turkey (8 } \\
\text { markets) }\end{array}$ & $\begin{array}{c}\text { Turkey } \\
\text { (Breeders) }\end{array}$ \\
\hline Vitamin A (MIU) & 7.0 & 7.0 & 6.0 & 8.0 & 9.0 & 7.0 & 9.0 \\
Vitamin E (TIU) & 6.0 & 6.0 & 5.0 & 10.0 & 11.0 & 8.0 & 30.0 \\
Mn (mg) & 25.0 & 25.0 & 50.0 & 75.0 & 50.0 & 50.0 & 50.0 \\
Zn (mg) & 25.0 & 25.0 & 50.0 & 75.0 & 50.0 & 50.0 & 50.0 \\
Se (mg) & 0.05 & 0.05 & 0.05 & 0.05 & 0.1 & 5.1 & 0.1 \\
Cu (mg) & 5.0 & 5.0 & 5.0 & 5.0 & 5.0 & 5.0 & 5.0 \\
Fe (mg) & 50.0 & 50.0 & 50.0 & 50.0 & 50.0 & 50.0 & 50.0 \\
\hline \hline
\end{tabular}

MIU = million international unit; TIU = thousand international unit; $\mathrm{mg}=$ milligram.

vitamin E (Juin et al., 2007). Brenes et al. (2008) concluded that the antioxidant potency of GP was as effective as that of vitamin $\mathrm{E}$ and supplementing up to $60 \mathrm{~g} / \mathrm{kg}$ dosage of GP did not impair broiler performance. Moreover, dietary replacement of vitamin $E$ by sage leaves did not affect the performance and meat yield of spent hens (Loetscher et al., 2014). The negative feeding value of grape by-products has also been demonstrated. Supplementation of high concentrations of grape seed extract (Chamorro et al., 2013) and GP (Goni et al., 2007) impaired the growth rate and/or protein and amino acid digestibility of broilers. Current levels of dietary vitamin $\mathrm{E}$, particularly in pig and poultry production, is a safety margin to ensure the protection of animals in oxidative stress condition. It is imperative to acknowledge that the partial replacement of dietary vitamin $\mathrm{E}$ level with phenolic extracts require further research to avoid compromising the protective margin of the feed. This is emphatically important given that phenolic extracts exhibits their antioxidant activity via different mechanism compared with vitamin $\mathrm{E}$ as highlighted in previous sections in this review.

\section{Swine}

Zhu et al. (2012) indicated that antioxidant blend of vitamins $C$ and $E$, tea polyphenols, lipoic acid and microbial antioxidants has the potential to prevent free radical-induced damage in pigs and suppress oxidative stress by modulating the expression of tumor protein 53 and PGC $-1 \alpha$ genes post-weaning. The immuno-modulatory potential of tea polyphenol in piglets subjected to oxidative stress was supported by Deng et al. (2010). In addition, there was an increase in serum and liver $\alpha$-tocopherol levels in pigs supplemented with vitamin $\mathrm{E}$ (Ching et al., 2002). However, as the dietary levels of vitamins $A$ and $E$ increased, there was contrasting interaction that resulted in the decline of the $\alpha$-tocopherol levels in the tissues. Fernández-Dueñas et al. (2008) observed no effect on the antioxidant status measured in terms of TBARS concentration and GSH-Px activity in weaned pigs supplemented with vitamin $\mathrm{C}$ and $\beta$-carotene. Furthermore, TBHQ and EQ improved performance, decreased lipid oxidation and boosted the biological antioxidant system such as GSH-Px, SOD and CAT activities when pigs were fed oxidized corn oil (Fernández-Dueñas, 2009).

\section{Ruminants}

The transition or periparturient period is generally considered as a crucial time during which dairy cows are highly susceptible to oxidative stress (Sharma et al., 2011). The period is characterized by high metabolic demand and physiological adjustments to the onset of lactation. Abuelo et al. (2014) recently provided a review of the in vivo benefits of dietary antioxidants on udder health, uterine health and reproductive performance, and incidence of production diseases of periparturient cows. Insufficient dietary antioxidants during this period were suggested to possibly increase oxidative stress and occurrence of retained placenta in dairy cows (Brzezinska-Slebodzinska et al., 1994). However, supplementing transition cows and periparturient heifers with vitamin $E$ resulted in improved signs of oxidative status with regards to higher serum $\alpha$-tocopherol level, decreased lipid peroxidation and reduced oxidative damage in liver (Brzezinska-Slebodzinska et al., 1994; Bouwstra et al., 2008 and 2009). A meta-analysis of 19 experiments suggested that dietary addition of vitamin $\mathrm{E}$ and Se could decrease the average relative risk of mastitis by $34 \%$ (Zeiler et al., 2010). However, individual supplementation of Se was more potent in reducing the risk of mastitis compared with the individual supplementation of vitamin E (40\% v. 30\%). Moreover, dietary addition of vitamin $\mathrm{E}$ and Se apparently increased milk yield with mean of $1 \mathrm{~kg}$ milk/animal per day and this effect was greater for vitamin $\mathrm{E}$ than Se (Zeiler et al., 2010).

Furthermore, left displaced abomasum (LDA) is a significant health problem in dairy herd, especially during early lactation. Veterinary surgery aimed at repositioning the abomasum usually results in stress reaction that was found to be positively correlated to high level of plasma TBARS (Mudron et al., 2007). Qu et al. (2013) further found that the depletion of serum vitamin $E$ preceded the occurrence of LDA and persisted after LDA correction. These observations provided better insights to the role of oxidative stress in LDA cows both before and after surgical correction. However, Chawla and Kaur (2004) observed that plasma $\alpha$-tocopherol, retinol and $\beta$-carotene levels at parturition can be increased by supplementing cows with these vitamins during dry period in order to augment their immunity status. Supplementing heat-stressed lactating dairy cows with dietary selenium boosted the preventive antioxidant system of 
the animals (Calamari et al., 2011). In addition, dietary supplementation of vitamin $\mathrm{E}$ improved the semen quality of Aohan fine-wool sheep (Yue et al., 2010) while contrasting failure of fertility improvement was observed when vitamin $E$ and selenium were administered to lactating cows by injection (Paula-Lopes et al., 2003). This difference in observation may be partly attributed to the route of administration, which was suggested by Hansen (2010) as a factor that contributes to the effective concentration of antioxidant in tissues. It has been suggested that the present NRC requirement of dairy cows for antioxidant mineral nutrients should be considered as the minimum dietary requirement (Weiss, 2010). Therefore, necessary adjustments should be made when formulating diets to allow for expected differences due to intake, environment and feed composition (Table 3).

Environmental challenges such as heat stress, especially during summer period, could constitute serious welfare problems, which could impair the performance and health of livestock. Induction of oxidative stress has been suggested as major mechanism through which heat stress exert its negative effect on animals. There are indications that supplementation of vitamin $\mathrm{E}$ and selenium could attenuate some of the negative effects mediated by heat stress by improving the antioxidant status of sheep (Chauhan et al., 2014; Alhidary et al., 2015). However, the source of selenium (organic or inorganic) did not influence the performance of non-stressed beef heifers during the fattening phase (Rossi et al., 2015).

Ruminal acidosis is a metabolic disorder associated with feeding high quantity of readily fermentable carbohydrates to ruminants and it could impair animal productivity and cause detrimental health problems such as laminitis (Lettat et al., 2012). There are existing data that suggest the potential of dietary antioxidants to enhance rumen protection. Dietary inclusion of quercetin (a flavonoid with antioxidant capacity) in lamb diet decreased the level of parakeratosis, which is an indicator of subacute ruminal acidosis (Benavides et al., 2013). Moreover, dietary supplementation of either vitamin $\mathrm{E}$ or carsonic acids in concentrate diet corrected the metabolic acidosis in fattening lambs (Morán et al., 2013).
In general, despite the intriguing in vivo benefits of antioxidant supplementations in livestock species, there are some inconsistent results particularly with the supplementation of botanicals. The inconsistent effect of polyphenols may be related to the fact that in vitro studies were largely used to demonstrate their antioxidant properties. Most of these data may not be relevant to in vivo situation because of the uncertainty that phenolic compounds would be delivered to target tissues in concentrations that could elicit direct free radical scavenging effects. Moreover, the inconsistent effect of dietary antioxidants may be partly attributed to insufficient methodological approaches used for measuring biomarkers of oxidative stress in animals. Such discrepancies could be further attributed to experimental factors such as the loss of dietary antioxidants during feed processing and storage, dosage of antioxidants, antioxidant status of the animals before the experiment, age of animals, route of antioxidant administration, production traits, level of stress challenges and the level of natural antioxidants already present in the diets before supplementation. There is a need to seek adequate and standardized analytical methodologies to accurately measure biomarkers of oxidative stress in animals and subsequent effect of antioxidant supplementation. In addition, different elements of the experimental conditions particularly the animal factors should be clearly and extensively stated when reporting research results relating to antioxidant supplementations.

\section{Postmortem efficacy in livestock}

Oxidative rancidity imparts negatively on the sensory, nutritional and shelf-life qualities of food products (Valenzuela and Nieto, 1996), especially those high in PUFA such as meats (Morrissey et al., 1997). Consumption of lipid oxidation products that result from oxidative rancidity of animal products can be very toxic to human health (Esterbauer, 1993). Though, the addition of antioxidants in food processing has an age-long history; targeting antioxidant supplementation in animal diets may be a more potent strategy for enhancing the oxidative stability, sensory qualities and nutritional antioxidant content of animal products. In support of this assertion, lipid oxidation process

Table 3 Suggested dietary concentration (dry matter basis) of antioxidant mineral nutrients ${ }^{1}$ (adapted from Weiss, 2010)

\begin{tabular}{|c|c|c|c|c|c|}
\hline & \multicolumn{3}{|c|}{ Non-lactating cows } & \multicolumn{2}{|c|}{ Lactating cows } \\
\hline & Dry & Pre-fresh & Fresh & $50 \mathrm{lb}$ & $100 \mathrm{lb}$ \\
\hline Est. intake (lb/day) & 30 & 22 & 30 & 44 & 58 \\
\hline Vitamin A (IU/lb) & 3300 & 4500 & 3300 & 1850 & 1500 \\
\hline Vitamin E (IU/lb) & 35 & 50 & 25 & 12 & 10 \\
\hline Selenium (ppm) & 0.3 & 0.3 & 0.3 & 0.3 & 0.3 \\
\hline Copper (ppm) & 20 & 20 & 15 to 20 & 15 to 20 & 15 to 20 \\
\hline Manganese (ppm) & 30 to 50 & 40 to 50 & 40 to 50 & 30 to 40 & 30 to 40 \\
\hline Zinc (ppm) & 40 to 60 & 50 to 70 & 60 to 80 & 50 to 70 & 60 to 80 \\
\hline
\end{tabular}

${ }^{1}$ Values are for a Holstein cow with an average BW for various stages of lactation and gestation. Pre-fresh is for cows in the last 2 weeks of gestation. Fresh is for cows in the first 3 weeks of lactation. 
was thought to be initiated at the subcellular membrane level of muscle foods (Gray and Pearson, 1987) and dietary antioxidants can better incorporate into tissue membranes due to inherent in vivo metabolism rather than the superficial contact made by the postmortem addition of exogenous antioxidants (Liu et al., 1995).

\section{Meat}

Improvement in meat color and lipid oxidative stability as well as drip loss prevention by dietary antioxidant supplementations were previously reviewed (Liu et al., 1995; Wood and Enser, 1997). Supplementation of vitamin E and rosemary powder for broiler chickens increased the oxidative stability of fats in meat measured in terms of the MDA content (Marcinčák et al., 2005). Similarly, dietary $\alpha$-tocopherol supplementation reduced the TBARS content, lipid oxidation, rancid odor and flavor in raw, cooked and stored meat (Maraschiello et al., 1999; Grau et al., 2001; Ruiz et al., 2001; Tavarez et al., 2010; Taulescu et al., 2011). Taulescu et al. (2011) further observed an increased concentration of $\alpha$-tocopherol in meat due to supplementation with vitamin $\mathrm{E}$ or vitamin $\mathrm{E}$ with $\mathrm{Se}$, which implies an enriched antioxidant status of the meat for benefits in human nutrition. Mercier et al. (2000) suggested that dietary $\alpha$-tocopherol exhibits its antioxidant mechanism via increase in the free sulfhydryl present in muscle cell which then helps to trap free radicals from the cells, thereby protecting the cell membrane from oxidative degeneration during storage. On the contrary, dietary addition of marigold xanthophylls reduced the oxidative stability of meat as indicated by the increased TBARS content (Koreleski and Świątkiewicz, 2007). This suggests that there should be careful consideration for the use of new antioxidant substances, particularly plant extracts, with respect to their effect on meat quality.

Furthermore, the shelf life of pork from pigs fed oxidized corn oil supplemented with TBHQ and EQ was positively impacted by decreased discoloration and lipid oxidation (TBARS) after $0,7,14$ and 21 days in retail display (Fernández-Dueñas, 2009). However, Haak et al. (2008) observed no effect on color and protein oxidation of pork when $\alpha$-tocopherol and rosemary were supplemented in the diets of pigs. In contrast to rosemary supplementation that further depicts lack of effect on lipid oxidation in both raw and cooked pork, there was decrease in lipid oxidation in $\alpha$-tocopherol supplemented raw pork with exception to the cooked one.

Realini et al. (2004) observed that vitamin E supplementation of concentrate-fed steers increased lipid stability of ground beef and steaks but not color stability. On the other hand, vitamin C addition to ground beef improved color stability without altering lipid oxidation. Liu et al. (1995) reviewed that dietary vitamin E supplementation could have greater positive impacts in preventing discoloration as well as lipid oxidation in ground and frozen beef than cooked beef. However, the authors further noted that the adoption of $500 \mathrm{IU} /$ steer per day of vitamin $\mathrm{E}$ based on results from accumulated studies, may pose a threat to the cost effectiveness of the American beef industry unless adequate quantitative strategy can be developed for detecting at slaughter, beef fed such amount of vitamin $\mathrm{E}$. Moreover, changing beef heifers from inorganic to organic selenium during the last 2 months of fattening could be an effective way to enhance the qualities of meat from beef heifers (Rossi et al., 2015).

\section{Milk}

Dietary supplementation of antioxidants in dairy cows could be an effective way of fortifying milk and dairy products with antioxidant nutrients such as vitamins and minerals, while also promoting animal health (Baldi and Pinotti, 2008). The quality of milk can be compromised due to high somatic cell counts (SSC) resulting from incidence of mammary gland infection predominantly mastitis (Castillo et al., 2013). More importantly, SSC is one of the significant factors that determine milk price as it is considered as a gauge for the hygienic quality of milk. A review by Politis (2012) suggested that dietary vitamin $\mathrm{E}$ can improve milk quality either by directly enhancing the oxidative stability of milk or by indirectly reducing the level of SSC and plasmin activity in milk. Dietary antioxidants including vitamin E, Se and other trace minerals could reduce the occurrence of intramammary infection and thus decrease the SSC in milk (Baldi et al., 2000; Politis et al., 2004; Machado et al., 2013). However, antioxidant effect to reduce the SSC in milk has been inconsistent across studies (Sivertsen et al., 2005; Waller et al., 2007). Nonetheless, the meta-analysis by Zeiler et al. (2010) showed that supplementation of vitamin E and Se could decrease SSC by 24000 cells/ml milk. Vitamin E supplementation has also been shown to decrease plasmin by $30 \%$, a proteolytic enzyme that could compromise the processing quality of milk (Politis et al., 2004).

Antioxidant supplementations could also have positive influence on milk composition. Pre- and postpartum intramuscular injections of $\mathrm{Se}, \mathrm{Zn}$ and vitamin $\mathrm{E}$ improved the lipid profile of ovine milk (Gabryszuk et al., 2007). Similarly, antioxidant blend of pineapple rind, $\mathrm{Zn}$ and $\mathrm{Cu}$ had positive effect on blood and milk cholesterol and lactose content of goat milk (Warly et al., 2011). In contrast, there was no effect of vitamin $E$ supplementation on milk composition of lactose, fat and protein (Baldi et al., 2000; Politis et al., 2004).

\section{Egg}

Food enriched in n-3 fatty acids have been widely acknowledged for their health, growth and development benefits in humans (Simopoulos, 1991). It is clearly evident that increasing the content of these fatty acids in animal diets will simultaneously increase their availability in animal products including eggs (Meluzzi et al., 2000). However, the role of n-3 fatty acids was positively correlated to lipid peroxidation of tissues (Husvéth et al., 2000), which implies that animal products obtained from such feeding strategies will be more susceptible to rancid spoilage. Meluzzi et al. (2000) observed 
that dietary vitamin $\mathrm{E}$ prevents alteration in the fatty acid profile of the yolk after 28 days of storage while also enriching the table eggs with $\alpha$-tocopherol as the level of dietary vitamin $\mathrm{E}$ increases. In a comparative study involving supplementation of vitamin $E$ and rosemary extract, similar positive antioxidant effect of vitamin $E$ was found but rosemary extract had no effect on peroxidation of fresh eggs and when subjected to iron-induced lipid oxidation (Galobart et al., 2001). Though the tenuous effect observed for rosemary extract may be attributed to the low dietary dosage used in the study. In addition, dietary organic selenium was suggested to improve egg fertility and hatching quality of stored eggs obtained from broiler breeders fed PUFA-rich diets (Pappas et al., 2005 and 2006).

\section{Regulatory review for authorization of antioxidants as feed additives}

In most countries, a company intending to place a feed additive product on the market is legally required to obtain prior authorization via a process termed marketing authorization. To accomplish the authorization process for a product, a technical dossier application must be submitted to the relevant regulatory authorities according to the required standards and regulations. Figure 3 depicts the authorization process for feed additives in the EU. The regulatory jurisdictions for the technical dossier application of feed additives differs across countries. Commission Regulation (EC) No 1831/2003 authorized antioxidant substances as feed additives mainly for their efficacy in preventing oxidative damage and preserving the quality of feedstuffs and feed materials (Commission Regulation, 2003). Commission Regulations No 1831/2003 and 429/2008 (Commission Regulation, 2003 and 2008). detailed the established procedures for submitting the dossier application for feed additives in the EU. To consider the in vivo and postmortem effects of antioxidants, the review of existing EU legislations will have significant implication on the legislative classification of antioxidants and the efficacy assessment in the dossier application.

\section{Implication on the categorization of antioxidants}

An unequivocal feature of the regulatory jurisdictions in the EU, Canada, Brazil, China, Japan, South Africa and United States is that the claim or function of an ingredient or additive can change the regulatory category of such ingredient (Smedley, 2013). Hence, regulatory review for consideration of in vivo and postmortem efficacy claims of antioxidants may require the establishment of new functional category in the EU legislation for feed additives.

\section{Potential category based on in vivo efficacy claims} Increasing number of efficacy claims has been attributed to feed additives such as enzymes, probiotics, prebiotics and phytogenics. Consequently, different proposals have been presented by the feed additive industry to urge for the amendment of the existing EU legislations for feed additives. It is very obvious that increasing consumers' interests in issues like animal welfare and environmental sustainability are rapidly shaping the livestock sector in the EU. As such, the dynamics of this tremendous influence should encompass the entire livestock chain including the feed additive sector. Thus, there is need to propose a new category in the regulatory framework to explicitly accommodate feed additives that could 'favorably affect the welfare of animals'. In this potential category, there are two functional groups under which antioxidants can be proposed: (1) antioxidants as substances that will positively influence the

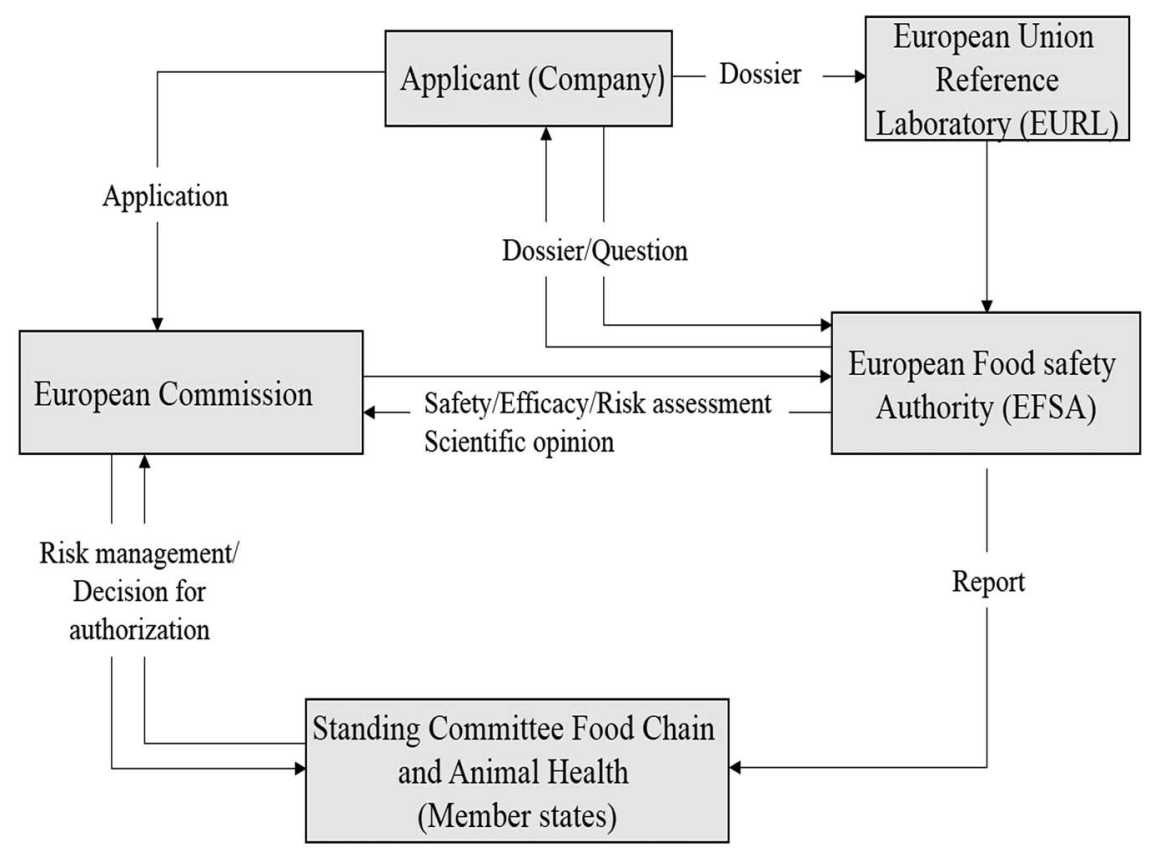

Figure 3 Authorization scheme for feed additives in the European Union (adapted from Jans D., personal communication). 
immune function of animals (i.e. immuno-modulators), (2) antioxidants as substances that will act within the animal to correct undesired consequences of nutritional origin (i.e. metabolic regulators).

\section{Potential category based on postmortem efficacy claims}

The quality of animal products encompasses the nutritional, sensory, safety and shelf-life values of the product. The existing category for 'sensory additives' can be reviewed to generally include feed additives used to 'improve animal product qualities'. Thus, 'sensory additives' should be stipulated as a functional group under a potential category for feed additives used to 'improve animal product qualities'. Three potential functional groups can be proposed for antioxidants in this new category: (1) antioxidants as substances intended to improve the sensory characteristics and product acceptance of animal products (i.e. sensory additives), (2) antioxidants as substances intended to improve the nutritional characteristics of animal products (i.e. nutrition enhancers), (3) antioxidants as substances used for prolonging the shelf life of animal products (i.e. shelf-life extenders).

\section{Implication on efficacy assessment for in vivo effects}

The demonstration of product efficacy is often considered as one of the most demanding and expensive requirements in the dossier application for authorization of feed additives. Apparently, failure to adequately demonstrate the efficacy of a product in the dossier application by any applicant (i.e. feed additive manufacturer) will hamper the success of the application and result into denial of market approval for such product. As opposed to the routine in vitro trials that are currently used for demonstrating the efficacy claims of antioxidants in dossier applications, in vivo and postmortem efficacy of antioxidants will keenly require documentation of in vivo trials. The extrapolation of in vivo effects of dietary antioxidants from in vitro trials could have some limitations due to lack of consideration for antioxidant uptake from the gastrointestinal tract and subsequent metabolism (Collins, 2005; Papić and Poljšak, 2012). However, measurements of oxidative stress and in vivo efficacy of antioxidants is presently one of the greatest challenges confronting oxidation research. Palmieri and Sblendorio (2007) extensively reviewed the assays involved in the measurements of oxidative stress and antioxidant intervention in biological organisms. As such, this review will only provide an overview of the commonly used methodologies.

\section{Indirect measurements of in vivo efficacy}

These consist of methods that measure the effect of free radicals on a biological system including direct damage to cell membranes.

\section{Membrane stability assay}

The correlation between antioxidant status of the animal and the stability of its cells' membranes is evident and this has led to the development of an analytical approach aimed at measuring the ability of the cell membrane to resist hemolysis (Sadique et al., 1989). This method provides simple and rapid measurements of oxidative stress and the in vivo efficacy of dietary antioxidant supplementation in animals.

\section{Measurement of total antioxidant activity}

Measuring the overall antioxidant status of the biological system may be more important than the measurement of any single antioxidant. Methods described by Miller et al. (1993b) can be used, as well as the ferric reducing ability of plasma (FRAP) value measurement methods described by Benzie and Strain (1996). The FRAP method is principally based on the reduction of the ferric-tripyridyltriazine $\left(\mathrm{Fe}^{3+}-\mathrm{TPTZ}\right)$ complex to the ferrous $\left(\mathrm{Fe}^{2+}\right)$ form at low $\mathrm{pH}$.

\section{Measurement of antioxidant enzymes}

Changes in antioxidant enzyme activity in erythrocytes have also been used to measure oxidative stress. The enzymes commonly measured include SOD, CAT and GSH-Px. CAT activities in the erythrocyte and tissue can be measured according to the method of Aebi (1984), GSH-Px activities by the method of Beutler (1975) and SOD activities by the method of Arthur and Boyne (1985). It is crucial to understand that the fate of free radicals on antioxidant enzymes could confound the interpretation of results. Free radicals could either depress the concentration/activity of these antioxidant enzymes by activating their damage or increase their concentration by stimulating their induction via endogenous protective mechanism (Palmieri and Sblendorio, 2007).

\section{Measurement of non-enzymatic antioxidants}

Vitamins $A, C$ and $E$, selenium, uric acid and to a lesser extent $\beta$-carotene, are principal non-enzymatic components of the biological antioxidant system. Vitamins $A$ and $E$ in serum and liver can be analyzed by HPLC following the procedures described by Catignani (1986). Selenium concentrations in blood and tissues can be measured using the fluorometric method by Rodriguez et al. (1994). The serum uric acid can, however, be determined using a chromogenic system described by Fossati et al. (1980).

\section{Measurement of GSH levels}

GSH level in the biological system of an animal is an important biomarker for oxidative stress and likewise for indicating the antioxidant status of an animal. Specifically, reduced GSH to oxidized GSH ratio decreases under oxidative conditions. Quite a number of assays including that of Guntherberg and Rost (1966), and Griffith (1980) are utilized to measure the GSH levels in biological tissues.

\section{Measurement of products of lipid peroxidation}

Biomarkers of lipid peroxidation in biological systems include MDA, lipid hydroperoxides ( $\mathrm{LOOH})$, isoprostanes and conjugated dienes. MDA and TBARS are probably the most commonly applied test system for lipid peroxidation in livestock (Botsoglou et al., 1994; Jo and Ahn, 1998; Young et al., 2003). Tissue MDA level and plasma MDA based on coupling 
with TBARS can be assayed according to the methods of Ohkawa et al. (1979) and Yagi (1984), respectively. TBARS is a well-recognized and established method for quantifying lipid peroxides. However, it has been largely criticized for its reactivity towards compounds other than MDA which consequently contribute to the unreliability of the results obtained from these assays. $\mathrm{LOOH}$ are formed earlier in the pathway leading to MDA. HPLC (chemiluminescence) and enzymatic methods can be utilized to detect $\mathrm{LOOH}$ in blood and tissues (Han et al., 2000). MDA determination could therefore be coupled with the HPLC method to improve the selectivity of the MDA assays. In addition, F2-isoprostanes and prostaglandinlike compounds in biological tissues can be measured as biomarkers of oxidative stress using gas chromatography-mass spectroscopy (Roberts and Morrow, 1994).

\section{Measurement of protein and DNA oxidation}

Changes in conjugated protein carbonyls can also serve as useful biomarkers for oxidative stress. When reactive oxygen species attack amino acids, carbonyl groups are produced and variety of assays has been developed to measure protein oxidation. These include HPLC and ELISA procedures (Griffiths, 2000; Han et al., 2000). However, many of these methods have been criticized for being unreliable and non-specific, coupled with the controversial debate of whether or not carbonyls represent good markers of protein oxidation in vivo (Balasubramanian et al., 1990; Stadtman and Oliver, 1991; Stadtman and Berlett, 1997).

\section{Measurement of stress or heat shock proteins (HSP)}

Expressions of HSP are regarded as manifestation of the endogenous protective mechanism against free radical damage. Stress protein synthesis has been explored as biomarker to assess the effect of oxidative stress on cellular defense system, and the counter-effect of antioxidant interventions (Wang and Edens, 1994; Polla, 1998; Goldbaum and Richter-Landsberg, 2001). Immunoblot technique can be used for analyzing stress proteins such as HSP70, HSP60, HSP32, HSP25 and $\alpha$ B-crystallin at cytological level as described by Goldbaum and Richter-Landsberg (2001). However, the interpretation of results can be very complicated as the expression of HSP could be induced by several stressor stimuli including hyperoxia, heat shock and oxidative stress.

\section{Direct measurements of in vivo efficacy}

Few techniques have also been developed to directly measure the level of specific reactive oxygen species present in a biological system. While these assays are robust enough to provide more precise quantification of the antioxidant status of a biological organism, their technical complexity and exorbitant analytical costs have undermined their frequency of use in oxidation research.

\section{Electron spin resonance spectroscopy method}

Collaborative utilization of this method with the spin trapping techniques can be used to directly measure free radical species in the blood and tissue samples. It is currently considered as the most sensitive direct measure of free radicals. Yoshiki et al. (1998) provided a description of how electron spin resonance could be used to measure superoxide free radicals.

\section{Lucigenin-derived chemiluminescence (LDCL) method}

This method is considered as one of the most sensitive techniques for superoxide free radical anion $\left(\mathrm{O}_{2-}\right)$ detection. The LDCL has been used to reliably measure the $\mathrm{O}_{2}$ - produced in isolated mitochondria and cultured endothelial cells (Li et al., 1999; Barbacanne et al., 2000). The exclusive advantage of this method is its high specificity to interact with the superoxide anion (Allen, 1986).

Indeed, several biochemical reactions are involved in the prooxidant-antioxidant balance of the biological organism. Critical evaluation of the above methodologies has suggested that many of the different assays and biomarker measurements should be applied simultaneously and the related information should be combined in order to obtain more precise results (Del Rio et al., 2002; Collins, 2005; Palmieri and Sblendorio, 2007). For accurate interpretation of the results, the relevance of the biomarkers needs to be understood in relation to their pathological and physiological significance (Del Rio et al., 2002). To reduce the cost of trials required for the efficacy assessment in the dossier application, in vivo results obtained from what are defined as major species can be extrapolated to other physiologically similar species. For instance, results obtained in laying hens may be extrapolated to other poultry species. Thus, it would be worthwhile to focus on research efforts aimed at developing accurate extrapolation models from in vivo studies between physiologically similar species.

\section{Implication on efficacy assessment for postmortem effects}

Postmortem effects of antioxidants can be measured using routine methods currently utilized for testing product quality efficacy of feed additives. Oxidative stability of animal products measured in terms of TBARS, water binding capacity of meat, product color measurement and antioxidant nutrient content in meat, egg and milk, are all important parameters to be measured to demonstrate the postmortem efficacy of antioxidant.

\section{Major challenge: antioxidants as feed additives or veterinary drugs?}

The in vivo efficacy claims may entangle antioxidants in the legislative controversy of either to be considered as veterinary drugs or feed additives. If antioxidants are to be considered as veterinary drugs, they will be subjected to stricter authorization procedures relevant to veterinary products and not those for feed additives. This may require extensive resources to document the safety and efficacy assessment for dossier application. Subsequently, this may 
significantly increase the duration and cost of securing authorization for such antioxidant products. However, there seems to be a twisted distinction between the description of feed additives and those of veterinary products in Commission Regulation (EC) 1831/2003. This distinction is essentially based on the requirement for zootechnical additives to 'affect favorably the performance in good health' contrary to veterinary products used to treat specific disorders (Smedley, 2013). Although this distinction is not as fundamental as it may first appear, such intrinsic opportunities can be debated since antioxidants are not intended to diagnose or cure diseases as ascribed to veterinary products.

\section{Implication on application of antioxidant feed additives}

Though antioxidants are currently not market-authorized for their in vivo and postmortem efficacy claims, they have been traditionally used in livestock practices to reduce stress conditions in animals and for improving animal product quality. Most of these antioxidant products are currently marketed and used under the labels of 'vitamin and mineral additives' as well as 'zootechnical additives' in the case of plant extracts and herbs. However, some dietary antioxidants could act as prooxidants particularly when supplemented in excess dosage. Prooxidants can induce oxidative stress in biologic system by increasing the production of reactive free radicals or depleting the antioxidant defense system to cause cellular damage (Palozza, 1998). Thus, prooxidants could exert detrimental effects on animal health and product quality in contrast to antioxidants. There are available data that showed the potential prooxidant effect of vitamin $\mathrm{E}$ (Pearson et al., 2006; Ouchi et al., 2009), vitamin C (Podmore et al., 1998), carotenoids (Palozza, 1998), synthetic antioxidants (Kahl et al., 1990) and phenolic compounds (Fukumoto and Mazza, 2000; Simić et al., 2007). It is noteworthy that the in vivo prooxidant effect of carotenoids and vitamins $C$ and $E$ has triggered much criticisms (Bland, 1998; Young and Lowe, 2001; Hathcock et al., 2005) and their prooxidant activity is yet to be convincingly proven due to sparse and conflicting data. Moreover, antioxidant substances such as vitamins are currently market-authorized without maximum inclusion limit in the feed. Nonetheless, there is need for in-depth research to ascertain the in vivo relevance of high dosage of antioxidant substances with regard to their potential to exhibit prooxidant effect.

Future use of antioxidants in livestock production will be driven tremendously by the increasing trend for intensive livestock production which simultaneously will elevate the exposure of animals to oxidative stress conditions. Similarly, increasing consumers' demand for high quality and functional animal foods would continue to escalate the demand for antioxidants in animal nutrition. The exclusive authorization of antioxidants based on their in vivo and postmortem benefits in livestock will stimulate the innovation of more potent antioxidant products and help to avoid indiscriminate use of antioxidants due to specification of claims and dosage on the product labels. In addition, it will better guide animal nutritionists in making dietary recommendations and enable livestock farmers to make better purchasing decisions that will improve their profitability. Appraisal of antioxidant registration system may also open potential new markets for feed antioxidants. However, legislative questions on antioxidant dosage and dose restriction need to be answered and may have to be demonstrated in the safety assessment of the dossier application.

\section{Conclusion}

With respect to the opinions presented in this review paper, it is anticipated that future feed additive legislations in the EU and possibly including other countries, would recognize the in vivo and postmortem efficacy of antioxidants. Appraisal of EU legislations on antioxidant registration require adequate data to address many of the knowledge gaps identified in this review. Thus, there is esteem need for additional investment in antioxidant-related research in production animals. Moreover, extensive future research should aim at developing more potent dietary antioxidant products as well as feeding strategies for effective delivery of antioxidant solutions to livestock. For these optimisms to be achieved, relevant stakeholders in the feed additive industry should dedicate concerted efforts to antioxidant research and lobby for the review of existing EU legislations guiding the authorization of antioxidants. Organizations such as the EU Feed Additives and Premixtures Association and the European Manufacturers of Feed Minerals Association (EMFEMA) could play major roles in this regard.

\section{Acknowledgments}

S. A. Salami, A. Guinguina, J. O Agboola and U. Tayyab are grateful to the European Commission for the scholarship support received towards the EMSANF program. The authors also acknowledge Olivier Clech and Paul Engler both of Nor-feed Sud (Angers, France) for revising the manuscript and providing useful suggestions for improvement. In addition, the authors are sincerely indebted to the two anonymous reviewers for their critical comments that contributed greatly to the perfection of this manuscript.

\section{References}

Abuelo A, Hernández J, Benedito JL and Castillo C 2014. The importance of the oxidative status of dairy cattle in the periparturient period: revisiting antioxidant supplementation. Journal of Animal Physiology and Animal Nutrition 99, 1003-1016.

Aebi H 1984. Catalase in vitro. Methods in Enzymology 105, 121-126.

Alhidary IA, Shini S, Al Jassim RAM, Abudabos AM and Gaughan JB 2015. Effects of selenium and vitamin $E$ on performance, physiological response, and selenium balance in heat-stressed sheep. Journal of Animal Science 93 576-588.

Allen RC 1986. Phagocytic leukocyte oxygenation activities and chemiluminescence: a kinetic approach to analysis. Methods in Enzymology 133, 449-493.

Aoki Y, Kotani A, Miyazawa N, Uchida K, Igarashi Y, Hirayama N, Hakamata H and Kusu F 2010. Determination of ethoxyquin by high-performance liquid chromatography with fluorescence detection and its application to the survey of 
residues in food products of animal origin. Journal of AOAC International 93, 277-283.

Arthur JR and Boyne R 1985. Superoxide dismutase and glutathione peroxidase activities in neutrophils from selenium deficient and copper deficient cattle. Life Sciences 36, 1569-1575.

Augustyniak A, Bartosz G, Cipak A, Duburs G, Horáková LU, Luczaj W, Majekova M, Odysseos AD, Rackova L, Skrzydlewska E, Stefek M, Strosova M, Tirzitis G, Venskutonis PR, Viskupicova J, Vraka PS and Zarkovic N 2010. Natural and synthetic antioxidants: an updated overview. Free Radical Research 44, 1216-1262.

Balasubramanian D, Du X and Zigler JS 1990. The reaction of singlet oxygen with proteins, with special reference to crystallins. Photochemistry and Photobiology 52, 761-768.

Baldi A and Pinotti L 2008. Lipophilic microconstituents of milk. In Bioactive components of milk (ed. Z Bosze), pp. 109-125. Springer, New York, NY, USA.

Baldi A, Savoini G, Pinotti L, Monfardini E, Cheli F and Orto VD 2000. Effects of vitamin $E$ and different energy sources on vitamin $E$ status, milk quality and reproduction in transition cows. Journal of Veterinary Medicine Series A 47, 599-608.

Barbacanne MA, Souchard JP, Darblade B, llious JP, Nepveu F, Pipy B and Arnal JF 2000. Detection of superoxide anion released extracellularly by endothelial cells using cytochrome reduction, ESR, fluorescence and lucigenin-enhanced chemiluminescence techniques. Free Radical Biology and Medicine 29, 388-396.

Benavides J, Martínez-Valladares M, Tejido ML, Giráldez FJ, Bodas R, Prieto N, Pérez V and Andrés S 2013. Quercetin and flaxseed included in the diet of fattening lambs: effects on immune response, stress during road transport and ruminal acidosis. Livestock Science 158, 84-90.

Benzie IFF and Strain JJ 1996. The ferric reducing ability of plasma (FRAP) as a measure of 'antioxidant power': the FRAP assay. Analytical Biochemistry 239, 70-76.

Beutler EA 1975. Red cell metabolism: a manual of biochemical methods, 2nd edition. Grune and Stratton Inc., New York, NY, USA.

Bland JS 1998. The pro-oxidant and antioxidant effects of vitamin C. Alternative Medicine Review: A Journal of Clinical Therapeutic 3, 170-173.

Błaszczyk A, Augustyniak A and Skolimowski J 2013. Ethoxyquin: an antioxidant used in animal feed. International Journal of Food Science 2013, 1-12.

Bohn T, McDougall GJ, Alegría A, Alminger M, Arrigoni E, Aura AM, Brito C, Cilla A, El SN, Karakaya S, Martínez-Cuesta MC and Santos CN 2015. Mind the gap - deficits in our knowledge of aspects impacting the bioavailability of phytochemicals and their metabolites - a position paper focusing on carotenoids and polyphenols. Molecular Nutrition and Food Research 59, 1307-1323.

Bohne VJB, Lundebye AK and Hamre K 2008. Accumulation and depuration of the synthetic antioxidant ethoxyquin in the muscle of Atlantic salmon (Salmo salar L.). Food and Chemical Toxicology 46, 1834-1843.

Botsoglou NA, Fletouris DJ, Papageorgiou GE, Vassilopoulus VN, Mantis AJ and Trakatellis AG 1994. Rapid, sensitive and specific thiobarbituric acid method for measuring lipid peroxidation in animal tissue, food and feedstuff samples. Journal of Agricultural and Food Chemistry 42, 1931-1937.

Bou R, Guardiola F, Grau A, Grimpa S, Manich A, Barroeta A and Codony R 2001. Influence of dietary fat source, alpha-tocopherol, and ascorbic acid supplementation on sensory quality of dark chicken meat. Poultry Science 80 , 800-807.

Bouwstra RJ, Goselink RMA, Dobbelaar P, Nielen M, Newbold JR and Van Werven $T$ 2008. The relationship between oxidative damage and vitamin $E$ concentration in blood, milk, and liver tissue from vitamin E supplemented and nonsupplemented periparturient heifers. Journal of Dairy Science 91, 977-987. Bouwstra RJ, Nielen M and Van Werven T 2009. Comparison of the oxidative status of vitamin E supplemented and nonsupplemented cows under field conditions. Tijdschrift Voor Diergeneeskunde 134, 656-661.

Brenes A, Viveros A, Chamorro S and Arija I 2016. Use of polyphenol-rich grape by-products in monogastric nutrition. A review. Animal Feed Science and Technology 211, 1-17.

Brenes A, Viveros A, Goni I, Centeno C, Sáyago-Ayerdy SG, Arija I and Saura-Calixto $F$ 2008. Effect of grape pomace concentrate and vitamin $E$ on digestibility of polyphenols and antioxidant activity in chickens. Poultry Science $87,307-316$.
Brzezinska-Slebodzinska E, Miller JK, Quigley JD, Moore JR and Madsen FC 1994. Antioxidant status of dairy cows supplemented prepartum with vitamin $E$ and selenium. Journal of Dairy Science 77, 3087-3095.

Buettner GR 1993. The pecking order of free radicals and antioxidants: lipid peroxidation, $\alpha$-tocopherol, and ascorbate. Archives of Biochemistry and Biophysics 300, 535-543.

Calabotta DF and Shermer WD 1985. Controlling feed oxidation can be rewarding. Feedstuffs 57, 2433.

Calamari LUIGI, Petrera F, Abeni F and Bertin G 2011. Metabolic and hematological profiles in heat stressed lactating dairy cows fed diets supplemented with different selenium sources and doses. Livestock Science 142, 128-137.

Castillo C, Pereira V, Abuelo Á and Hernández J 2013. Effect of supplementation with antioxidants on the quality of bovine milk and meat production. The Scientific World Journal 2013, 1-8.

Catignani GL 1986. An HPCL method for the simultaneous determination of retinol and $\alpha$-tocopherol in plasma or serum. Methods in Enzymology 123, 215-219.

Celi P 2011. Oxidative stress in ruminants. In Studies on veterinary medicine (ed. L Mandelker and P Vajdovich), pp. 191-231. Humana Press Inc., New York, NY, USA.

Celi P and Chauhan SS 2013. Oxidative stress management in farm animals: opportunities and challenges. In Proceedings of the 4th International Conference on Sustainable Animal Agriculture for Developing Countries, 27-31 July, Lanzhou, Gansu Province, China, pp. 95-109.

Chamorro S, Viveros A, Centeno C, Romero C, Arija I and Brenes A 2013. Effects of dietary grape seed extract on growth performance, amino acid digestibility and plasma lipids and mineral content in broiler chicks. Animal 7, 555-561.

Chauhan SS, Celi P, Leury BJ, Clarke IJ and Dunshea FR 2014. Dietary antioxidants at supranutritional doses improve oxidative status and reduce the negative effects of heat stress in sheep. Journal of Animal Science 92, 3364-3374.

Chawla $\mathrm{R}$ and Kaur $\mathrm{H}$ 2004. Plasma antioxidant vitamin status of periparturient cows supplemented with $\alpha$-tocopherol and $\beta$-carotene. Animal Feed Science and Technology 114, 279-285.

Ching S, Mahan DC, Wiseman TG and Fastinger ND 2002. Evaluating the antioxidant status of weanling pigs fed dietary vitamins $A$ and $E$. Journal of Animal Science 80, 2396-2401.

Collins AR 2005. Assays for oxidative stress and antioxidant status: applications to research into the biological effectiveness of polyphenols. American Journal of Clinical Nutrition 81, 261-267.

Commission Regulation (EC) 2003. Commission Regulation (EC) No 1831/2003 of the European Parliament and of the Council of 22 September 2003 on additives for use in animal nutrition. Official Journal of the European Union. Retrieved June 28, 2015, from http://faolex.fao.org/docs/pdf/eur40306.pdf.

Commission Regulation (EC) 2008. Commission Regulation (EC) No 429/2008 on detailed rules for the implementation of Regulation (EC) No 1831/2003 of the European Parliament and of the Council as regards the preparation and the presentation of applications and the assessment and the authorization of feed additives. Retrieved June 28, 2015, from http://faolex.fao.org/docs/pdf/ eur79099.pdf.

Crane SW, Griffin RW and Messent PR 2000. Introduction to commercial pet foods. Small Animal Clinical Nutrition 4, 111-126.

Decker EA 1998. Antioxidant mechanisms. In Food lipids: chemistry, nutrition and biotechnology (ed. CC Akoh and DB Min), pp. 397-421. CRC Press, Boca Raton, FL, USA.

Decker EA, Akoh CC and Wilkes RS 2012. Incorporation of (n-3) fatty acids in foods: challenges and opportunities. The Journal of Nutrition 142, 610-613.

Del Rio D, Serafini N and Pellegrini N 2002. Selected methodologies to asses oxidative/antioxidant status in vivo: a critical review. Nutrition, Metabolism and Cardiovascular Diseases 12, 343-351.

Deng Q, Xu J, Yu B, He J, Zhang K, Ding X and Chen D 2010. Effect of dietary tea polyphenols on growth performance and cell-mediated immune response of post-weaning piglets under oxidative stress. Archives of Animal Nutrition 64, 12-21.

Esterbauer H 1993. Cytotoxicity and genotoxicity of lipid-oxidation products. American Journal of Clinical Nutrition 57, 779-785. 
Fellenberg MA and Speisky H 2006. Antioxidants: their effects on broiler oxidative stress and its meat oxidative stability. World's Poultry Science Journal 62, 53-70.

Fernández-Dueñas DM 2009. Impact of oxidized corn oil and synthetic antioxidant on swine performance, antioxidant status of tissues, pork quality and shelf life evaluation. Thesis PhD, University of Illinois at Urbana-Champaign, Urbana, IL, USA.

Fernández-Dueñas DM, Mariscal G, Ramírez E and Cuarón JA 2008. Vitamin C and $\beta$ carotene in diets for pigs at weaning. Animal Feed Science and Technology 146, 313-326.

Fossati P, Principe L and Berti G 1980. Use of 3,5-dichloro-2-hydroxybenzene sulfonic acid/4-aminophenazone chromogenic system in the direct enzymic assay of uric acid in serum and urine. Clinical Chemistry 26, 227-231.

Fukumoto LR and Mazza G 2000. Assessing antioxidant and prooxidant activities of phenolic compounds. Journal of Agricultural and Food Chemistry 48 3597-3604.

Gabryszuk M, Strzałkowska N and Krzyżewski J 2007. Effects of pre- and postpartum injections of $\mathrm{Se}, \mathrm{Zn}$ and vitamin $\mathrm{E}$ on the concentration of cholesterol, CLA isomers and fatty acids in ovine milk. Animal Science Papers and Reports 25, 87-95.

Galobart J, Barroeta AC, Baucells MD, Codony R and Ternes W 2001. Effect of dietary supplementation with rosemary extract and $\alpha$-tocopheryl acetate on lipid oxidation in eggs enriched with $\omega 3$-fatty acids. Poultry Science 80, 460-467.

Goldbaum 0 and Richter-Landsberg C 2001. Stress proteins in oligodendrocytes: differential effects of heat shock and oxidative stress. Journal of Neurochemistry $78,1233-1242$.

Goni I, Brenes A, Centeno C, Viveros A, Saura-Calixto F, Rebolé A, Arija I and Estevez R 2007. Effect of dietary grape pomace and vitamin $E$ on growth performance, nutrient digestibility, and susceptibility to meat lipid oxidation in chickens. Poultry Science 86, 508-516.

Grau A, Guardiola F, Grimpa S, Barroeta AC and Codony R 2001. Oxidative stability of dark chicken meat through frozen storage: influence of dietary fat and $\alpha$-tocopherol and ascorbic acid supplementation. Poultry Science 80 1630-1642.

Gray JI and Pearson AM 1987. Rancidity and warmed-over flavor. Advances in Meat Research 3, 221-269.

Griffith OW 1980. Determination of glutathione and glutathione disulfide using glutathione reductase and 2-vinylpyridine. Analytical Biochemistry 106, 207-212.

Griffiths HR 2000. Antioxidants and protein oxidation. Free Radical Research 33, S47-S58.

Guntherberg $\mathrm{H}$ and Rost J 1966. The true oxidized glutathione content of red blood cells obtained by new enzymic and paper chromatographic methods. Analytical Biochemistry 15, 205-210.

Haak L, Raes K, Van Dyck S and De Smet S 2008. Effect of dietary rosemary and $\alpha$ - tocopheryl acetate on the oxidative stability of raw and cooked pork following oxidized linseed oil administration. Meat Science 78, 239-247.

Halliwell B and Gutteridge JMC 1999. Free radicals in biology and medicine, 3rd edition. Clarendon Press, Oxford, UK.

Han D, Loukianoff S and McLaughlin L 2000. Oxidative stress indices: analytical aspects and significance. In Handbook of oxidants and antioxidants in exercise (ed. Hanninen 0, Packer L and Sen CK), pp. 433-484. Elsevier, Amsterdam, TheNetherlands.

Hansen PJ 2010. Supplemental antioxidants to enhance fertility in dairy cattle. In 21st Annual FL Ruminant Nutrition Symposium, Gainesville, FL, USA pp. 157-166.

Hathcock JN, Azzi A, Blumberg J, Bray T, Dickinson A, Frei B, Jialal I, Johnston CS, Kelly FJ, Kraemer K, Packer L, Parthasarathy S, Sies H and Traber MG 2005. Vitamins $E$ and $C$ are safe across a broad range of intakes. The American Journal of Clinical Nutrition 81, 736-745.

Hilton JW 1989. Antioxidants: function, types and necessity of inclusion in pet foods. The Canadian Veterinary Journal 30, 682.

Husvéth F, Manilla HA, Gaal T, Vajdovich P, Balogh N, Wagner L, Loth I and Németh SK 2000. Effects of saturated and unsaturated fats with vitamin $E$ supplementation on the antioxidant status of broiler chicken tissues. Acta Veterinaria Hungarica 48, 69-79.

Iglesias J, Pazos M, Andersen ML, Skibsted LH and Medina I 2008. Caffeic acid as antioxidant in fish muscle: mechanism of synergism with endogenous ascorbic acid and $\alpha$-tocopherol. Journal of Agricultural and Food Chemistry 57, 675-681.

Jena BP, Panda N, Patra RC, Mishra PK, Behura NC and Panigrahi B 2013. Supplementation of vitamin $\mathrm{E}$ and $\mathrm{C}$ reduces oxidative stress in broiler breeder hens during summer. Food and Nutrition Sciences 4, 33-37.

Jensen SK and Lauridsen C 2003. Relative proportion of stereoisomers of alfa-tocopherol in fluids and tissues from rats, pigs, cows and poultry explains different bioactivity of dietary natural and synthetic vitamin $\mathrm{E}$ between different animal species. In Proceedings of the 9th Symposium of Vitamins and Additives in the Nutrition of Man and Animal, 24-25 September, Jena, Thüringen, Germany, pp. 136-141.

Jo C and Ahn DU 1998. Fluorometric analysis of 2-thiobarbituric acid reactive substances in turkey. Poultry Science 77, 475-480.

Juin H, Decousser A and Chicoteau P 2007. Incorporation of different grape extracts in the diet of broilers: effect on growth performance and stability of red blood cell membranes. In Actes des 7èmes Journées de la Recherche Avicole, Tours, France, pp. 212-214.

Kahl R, Weinke S and Kappus H 1990. Comparison of antioxidant and prooxidant activity of various synthetic antioxidants. In Antioxidants in therapy and preventive medicine (ed. I Emerit, L Packer and C Auclair), pp. 283-290. Springer, New York, NY, USA.

Kalam S, Singh R, Mani A, Patel J, Khan FN and Pandey A 2012. Antioxidants: elixir of life. International Multidisciplinary Research Journal 2, 18-34.

Koreleski J and Świątkiewicz S 2007. Dietary supplementation with plant extracts, xantophylls and synthetic antioxidants: effect on fatty acid profile and oxidative stability of frozen stored chicken breast meat. Journal of Animal and Feed Sciences 16, 463-471.

Lee JH, Khor TO, Shu L, Su ZY, Fuentes F and Kong ANT 2013. Dietary phytochemicals and cancer prevention: Nrf2 signaling, epigenetics, and cell death mechanisms in blocking cancer initiation and progression. Pharmacology and Therapeutics 137, 153-171.

Lettat A, Nozière P, Silberberg M, Morgavi DP, Berger C and Martin C 2012. Rumen microbial and fermentation characteristics are affected differently by bacterial probiotic supplementation during induced lactic and subacute acidosis in sheep. BMC Microbiology 12, 1-12.

Li Y, Stansbury KH, Zhu H and Trush MA 1999. Biochemical characterization of lucigenin (Bis-N-methylacridinium) as a chemiluminescent probe for detecting intramitochondrial superoxide anion radical production. Biochemical and Biophysical Research Communications 262, 80-87.

Lindqvist $\mathrm{H}$ 2012. $\alpha$-tocopherol and $\beta$-carotene in forages and their utilisation by dairy cows in organic production. Thesis PhD, Swedish University of Agricultural Sciences, Skara, Sweden.

Liu Q, Lanari MC and Schaefer DM 1995. A review of dietary vitamin E supplementation for improvement of beef quality. Journal of Animal Science 73, 3131-3140.

Loetscher Y, Kreuzer M, Albiker D, Stephan R and Messikommer RE 2014. Effect of replacing dietary vitamin $E$ by sage on performance and meatiness of spent hens and the oxidative stability of sausages produced from their meat. British Poultry Science 55, 576-584.

Lundebye AK, Hove $H$, Måge A, Bohne VJB and Hamre K 2010. Levels of synthetic antioxidants (ethoxyquin, butylated hydroxytoluene and butylated hydroxyanisole) in fish feed and commercially farmed fish. Food Additives and Contaminants: Part A 27, 1652-1657.

Lykkesfeldt $\mathrm{J}$ and Svendsen 0 2007. Oxidants and antioxidants in disease: oxidative stress in farm animals. The Veterinary Journal 173, 502-511.

Machado VS, Bicalho MLS, Pereira RV, Caixeta LS, Knauer WA, Oikonomou G, Gilbert RO and Bicalho RC 2013. Effect of an injectable trace mineral supplement containing selenium, copper, zinc, and manganese on the health and production of lactating Holstein cows. The Veterinary Journal 197, 451-456.

Maini S, Rastogi SK, Korde JP, Madan AK and Shukla SK 2007. Evaluation of oxidative stress and its amelioration through certain antioxidants in broilers during summer. The Journal of Poultry Science 44, 339-347.

Manach C, Scalbert A, Morand C, Rémésy C and Jiménez L 2004. Polyphenols: food sources and bioavailability. The American Journal of Clinical Nutrition 79, 727-747.

Maraschiello C, Sarraga C and Garcia Regueiro JA 1999. Glutathione peroxidase activity, TBARS, and $\alpha$-tocopherol in meat from chickens fed different diets. Journal of Agricultural and Food Chemistry 47, 867-872. 
Marcinčák S, Popelka P, Bystrický P, Hussein K and Hudecová K 2005. Oxidative stability of meat and meat products after feeding of broiler chickens with additional amounts of vitamin E and rosemary. MESO: prvi hrvatski časopis 0 mesu 7, 34-39.

Meluzzi A, Sirri F, Manfreda G, Tallarico N and Franchini A 2000. Effects of dietary vitamin $E$ on the quality of table eggs enriched with $n-3$ long-chain fatty acids. Poultry Science 79, 539-545.

Mercier Y, Gatellier P, Vincent A and Renerre M 2000. Lipid and protein oxidation in microsomal fraction from turkeys: influence of dietary fat and vitamin E supplementation. Meat Science 58, 125-134.

Miller JK, Brzezinska-Slebodzinska E and Madsen FC 1993aOxidative stress, antioxidants, and animal function. Journal of Dairy Science 76, 2812-2823.

Miller NJ, Rice-Evans C, Davies MJ, Gopinathan V and Milner A 1993bA novel method for measuring antioxidant capacity and its application to monitoring the antioxidant status in premature neonates. Clinical Science 84, 407-412.

Morán L, Giráldez FJ, Bodas R, Benavides J, Prieto N and Andrés S 2013. Metabolic acidosis corrected by including antioxidants in diets of fattening lambs. Small Ruminant Research 109, 133-135.

Morrissey PA, Brandon S, Buckley DJ, Sheehy PJA and Frigg M 1997. Tissue content of $\alpha$-tocopheryl acetate supplement for various periods pre-slaughter. British Poultry Science 38, 84-88.

Morrissey PA, Sheehy PJA, Galvin K, Kerry JP and Buckley DJ 1998. Lipid stability in meat and meat products. Meat Science 49, S73-S86.

Mudron P, Herzog K, Höltershinken M and Rehage J 2007. Effects of abdominal surgery on thiobarbituric acid reactive substances and plasma anti-oxidative capacity in dairy cows. Journal of Veterinary Medicine Series A 54, 441-444.

Ohkawa H, Ohishi $\mathrm{N}$ and Yagi K 1979. Assay for lipid peroxides in animal tissues by thiobarbituric acid reaction. Analytical Biochemistry 95, 351-358.

Ouchi A, Ishikura M, Konishi K, Nagaoka SI and Mukai K 2009. Kinetic study of the prooxidant effect of $\alpha$-tocopherol. Hydrogen abstraction from lipids by $\alpha$-tocopheroxyl radical. Lipids 44, 935-943.

Palmieri B and Sblendorio V 2007. Oxidative stress tests: overview on reliability and use. European Review for Medical and Pharmacological Sciences 11, 383-399.

Palozza P 1998. Prooxidant actions of carotenoids in biologic systems. Nutrition Reviews 56, 257-265.

Papić JO and Poljšak B 2012. Antioxidant potential of selected supplements in vitro and the problem of its extrapolation for in vivo. Journal of Health Sciences 2, 5-12.

Pappas AC, Acamovic T, Sparks NHC, Surai PF and McDevitt RM 2005. Effects of supplementing broiler breeder diets with organic selenium and polyunsaturated fatty acids on egg quality during storage. Poultry Science 84 , 865-874.

Pappas AC, Acamovic T, Sparks NHC, Surai PF and McDevitt RM 2006. Effects of supplementing broiler breeder diets with organoselenium compounds and polyunsaturated fatty acids on hatchability. Poultry Science 85, 1584-1593.

Paula-Lopes FF, Al-Katanani YM, Majewski AC, McDowell LR and Hansen PJ 2003. Manipulation of antioxidant status fails to improve fertility of lactating cows or survival of heat-shocked embryos. Journal of Dairy Science 86, 2343-2351.

Pearson P, Lewis SA, Britton J, Young IS and Fogarty A. 2006. The pro-oxidant activity of high-dose vitamin E supplements in vivo. BioDrugs 20, 271-273.

Podmore ID, Griffiths HR, Herbert KE, Mistry N, Mistry P and Lunec J 1998. Vitamin C exhibits pro-oxidant properties. Nature 392, 559.

Politis I 2012. Reevaluation of vitamin E supplementation of dairy cows: bioavailability, animal health and milk quality. Animal 6, 1427-1434.

Politis I, Bizelis I, Tsiaras A and Baldi A 2004. Effect of vitamin E supplementation on neutrophil function, milk composition and plasmin activity in dairy cows in a commercial herd. Journal of Dairy Research 71, 273-278.

Polla BS 1998. A role for heat shock protein in inflammation. Immunology Today 9, 134-137.

Qu Y, Lytle K, Traber MG and Bobe G 2013. Depleted serum vitamin E concentrations precede left displaced abomasum in early-lactation dairy cows. Journal of Dairy Science 96, 3012-3022.

Realini CE, Duckett SK, Brito GW, Dalla Rizza M and De Mattos D 2004. Effect of pasture vs. concentrate feeding with or without antioxidants on carcass characteristics, fatty acid composition, and quality of Uruguayan beef. Meat Science 66, 567-577.

Roberts LJ and Morrow JD 1994. Isoprostanes-novel markers of endogenous lipid peroxidation and potential mediators of oxidant injury. Annals of the New York Academy of Sciences 744, 237-242.

Rodriguez EM, Sanz MT and Romero CD 1994. Critical study of fluorometric determination of selenium in urine. Talanta 41, 2025-2031.

Rossi CS, Compiani R, Baldi G, Bernardi CEM, Muraro M, Marden JP and Dell'Orto V 2015. The effect of different selenium sources during the finishing phase on beef quality. Journal of Animal and Feed Sciences 24, 93-99.

Ruiz JA, Guerrero L, Arnau J, Guardia MD and Esteve-Garcia E 2001. Descriptive sensory analysis of meat from broilers fed diets containing vitamin $E$ or $\beta$-carotene as antioxidants and different supplemental fats. Poultry Science 80, 976-982.

Sadique J, Al-Rqobah WA, Bughaith MF and El-Gindy AR 1989. The bio-activity of certain medicinal plants on the stabilization of RBC membrane system. Fitoterapia 60, 525-532.

Salami SA, Majoka MA, Saha S, Garber A and Gabarrou JF 2015. Efficacy of dietary antioxidants on broiler oxidative stress, performance and meat quality: science and market. Avian Biology Research 8, 65-78.

Shahidi F 2000. Antioxidants in food and food antioxidants. Nahrung 44, 158-163.

Shahidi $F$ and Zhong $Y$ 2005. Antioxidants: regulatory status. In Industrial oil and fat products, 6th edition (ed. F Shahidi), pp. 491-512. John Wiley \& Sons Inc, Hoboken, NJ, USA.

Sharma N, Singh NK, Singh OP, Pandey V and Verma PK 2011. Oxidative stress and antioxidant status during transition period in dairy cows. Asian-Australasian Journal of Animal Science 24, 479-484.

Simić A, Manojlović D, Šegan D and Todorović M 2007. Electrochemical behavior and antioxidant and prooxidant activity of natural phenolics. Molecules 12, 2327-2340.

Simopoulos AP 1991. Omega-3 fatty acids in health and disease and in growth and development. American Journal of Clinical Nutrition 54, 438-463.

Sivertsen T, Overnes G, Osteras O, Nymoen U and Lunder T 2005. Plasma vitamin $\mathrm{E}$ and blood selenium concentrations in Norwegian dairy cows: regional differences and relations to feeding and health. Acta Veterinaria Scandinavica 46, 177-192.

Smedley KO 2013. Comparison of regulatory management of authorized ingredients, approval processes, and risk-assessment procedures for feed ingredients. Retrieved October 28, 2014, from http://www.ifif.org/uploadlmage/ 2013/7/19/272ee931adc6dacaadd762c71f8110a31374224070.pdf.

Stadtman ER and Berlett BS 1997. Reactive oxygen-mediated protein oxidation in aging and disease. Chemical Research in Toxicology 10, 485-494.

Stadtman ER and Oliver CN 1991. Metal-catalyzed oxidation of proteins. Physiological consequences. The Journal of Biological Chemistry 266, 2005-2008. Surai PF 2002. Natural antioxidants in avian nutrition and reproduction. pp. 5-9. Nottingham University Press, Nottingham, UK.

Surai PF 2007. Natural antioxidants in poultry nutrition: new developments. In Proceedings of the 16th European Symposium on Poultry Nutrition, 26-30 August, Strasbourg, France, pp. 669-675.

Taulescu C, Mihaiu M, Bele C, Matea C, Dan SD, Mihaiu R and Lapusan A 2011. Antioxidant effect of vitamin $E$ and selenium on omega-3 enriched poultry meat. Bulletin of University of Agricultural Sciences and Veterinary Medicine Cluj-Napoca. Veterinary Medicine 68, 293-299.

Tavarez MA, Boler DD, Bess KN, Zhao J, Yan F, Dilger AC, Mckeith FK and Killefer $J$ 2010. Effect of antioxidant inclusion and oil quality on broiler performance, meat quality, and lipid oxidation. Poultry Science 90, 922-930.

Topliss JG, Clark AM, Ernst E, Hufford CD, Johnston GAR, Rimoldi JM and Weimann BJ 2002. Natural and synthetic substances related to human health (IUPAC Technical Report). Pure and Applied Chemistry 74, 1957-1985.

Traber MG, Elsner A and Brigelius-Flohé R 1998. Synthetic as compared with natural vitamin $\mathrm{E}$ is preferentially excreted as $\alpha$-CEHC in human urine: studies using deuterated $\alpha$-tocopheryl acetates. FEBS Letters 437, 145-148.

Valenzuela A and Nieto S 1996. Synthetic and natural antioxidants: food quality protectors. Grasasy Aceites 47, 186-196.

Vossen $\mathrm{E}$, Ntawubizi $\mathrm{M}$, Raes $\mathrm{K}$, Smet $\mathrm{K}$, Huyghebaert G, Arnouts $\mathrm{S}$ and De Smet $S$ 2011. Effect of dietary antioxidant supplementation on the oxidative 


\section{Salami, Guinguina, Agboola, Omede, Agbonlahor and Tayyab}

status of plasma in broilers. Journal of Animal Physiology and Animal Nutrition 95 198-205.

Waldroup PW 2001. Dietary nutrient allowances for chickens and turkeys. Feedstuffs 73, 56-65.

Waller KP, Sandgren $\mathrm{CH}$, Emanuelson $\mathrm{U}$ and Jensen SK 2007. Supplementation of RRR- $\alpha$-tocopheryl acetate to periparturient dairy cows in commercial herds with high mastitis incidence. Journal of Dairy Science 90 , 3640-3646.

Wang S and Edens FW 1994. Hsp70 mRNA expression in heat stressed chickens. Comparative Biochemistry and Physiology Part B: Comparative Biochemistry 107, 33-37.

Warly L, Nurdin E and Rusmana WSN 2011. Milk quality of dairy goats by giving feed supplement as antioxidant source. Journal of the Indonesian Tropical Animal Agriculture 36, 205-212.

Weiser $\mathrm{H}$ and Vecchi M 1982. Stereoisomers of alpha-tocopheryl acetate. II. Biopotencies of all eight stereoisomers, individually or in mixtures, as determined by rat resorption-gestation tests. International Journal for Vitamin and Nutrition Research 52, 351-370.

Weiss WP 2010. Antioxidant nutrients and milk quality. Retrieved September 20, 2014, from http://www.extension.org/pages/23382/antioxidant-nutrients-andmilk-quality\#.VBI3YMJdXTY.

Wood JD and Enser M 1997. Factors influencing fatty acids in meat and the role of antioxidants in improving meat quality. British Journal of Nutrition 78, S49-S60.

Yagi K 1984. Assay for blood plasma or serum. Methods in Enzymology 105, 328-331.
Yardibi $\mathrm{H}$ and Turkay $\mathrm{G}$ 2008. The effects of vitamin $\mathrm{E}$ on the antioxidant system, egg production, and egg quality in heat stressed laying hens. Turkish Journal of Veterinary and Animal Sciences 32, 319-325.

Yeum KJ, Russell RM, Krinsky NI and Aldini G 2004. Biomarkers of antioxidant capacity in the hydrophilic and lipophilic compartments of human plasma. Archives of Biochemistry and Biophysics 430, 97-103.

Yoshiki Y, Huan H, Lida T, Kawane M, Okubo K, Ishizawa T and Kawabata S 1998. Chemiluminescence of horseradish peroxidase and acetaldehyde related with gallic acid and hydrogen peroxide interaction. Photochemistry and Photobiology 68, 802-808.

Young AJ and Lowe GM 2001. Antioxidant and prooxidant properties of carotenoids. Archives of Biochemistry and Biophysics 385, 20-27.

Young JF, Stagsted J, Jensen SK, Karlsson AH and Henckel P 2003. Ascorbic acid, alpha tocopherol, and oregano supplements reduce stress-induced deterioration of chicken meat quality. Poultry Science 82, 1343-1361.

Yue D, Yan L, Luo H, Xu X and Jin X 2010. Effect of Vitamin E supplementation on semen quality and the testicular cell membranal and mitochondrial antioxidant abilities in Aohan fine-wool sheep. Animal Reproduction Science 118, 217-222.

Zeiler E, Sauter-Louis C, Ruddat I, Martin R, Mansfeld R, Knubben-Schweizer G and Zerbe $\mathrm{H}$ 2010. Influence of vitamin $\mathrm{E}$ and selenium on udder health $-\mathrm{a}$ meta-analysis. Reproduction in Domestic Animals 61, 60-61.

Zhu LH, Zhao KL, Chen XL and Xu JX 2012. Impact of weaning and an antioxidant blend on intestinal barrier function and antioxidant status in pigs. Journal of Animal Science 90, 2581-2589. 